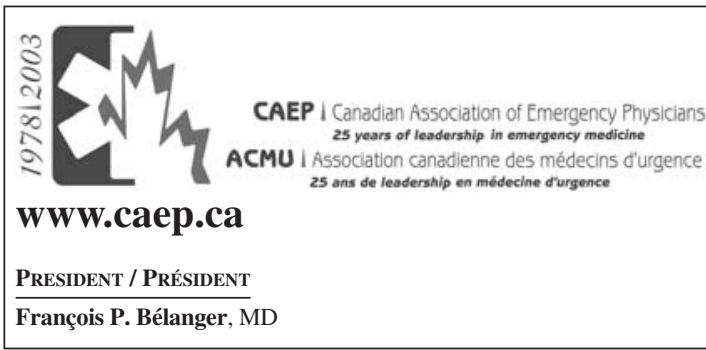

Canadian Journal of Emergency Medicine Journal canadien de la médecine d'urgence

EDITOR-IN-CHIEF / RÉDACTEUR EN CHEF

Grant Innes, MD ginnes@interchange.ubc.ca

University of British Columbia, Vancouver

SENIOR ASSOCIATE EDITORS / RÉDACTEURS ADJOINT

\begin{tabular}{lc}
\hline Garth Dickinson, MD & garth.dickinson@ $@$ rogers.com \\
University of Ottawa, Ottawa & \\
James Ducharme, MD & jim_ducharme@bigfoot.com \\
Dalhousie University, Saint John, NB
\end{tabular}

MANAGING EDITOR / RÉDACTRICE ADMINISTRATIVE

Heidi Innes, BSc, BEd ginnes@interchange.ubc.ca

ASSOCIATE EdITORS / RÉDACTEURS ASSOCIÉS

EM ADVANCES (original research)

Ian G. Stiell, MD, MSc, University of Ottawa, Ottawa

Jacques S. Lee, MD, University of Toronto, Toronto

CJEM JOURNAL CLUB

Michael J. Bullard, MD, University of Alberta, Edmonton

CASE REPORTS

Anthony S. Taylor, MD, University of Calgary, Calgary

SMALl URban AND RURAL ISSUES

James M. Thompson, MD, Dalhousie University, Charlottetown

Methodology: THE SCIENCE OF EM

Riyad B. Abu-Laban, MD, MHSc, University of British Columbia, Vancouver

PHARMACOTHERAPY

Peter J. Zed, BSc(Pharm), PharmD, University of British Columbia,

Vancouver

Jeff Eppler, MD, Kelowna General Hospital, Kelowna, BC

ED ADMINISTRATION

Jeremy M. Etherington, MD, St. Paul's Hospital, Vancouver

EDUCATION

Tim Allen, MD, Université Laval, Quebec City

State of the ART (review articles and topical updates)

Vacant

TOXICOLOGY

Roy Purssell, MD, University of British Columbia, Vancouver

CONTROVERSIES (issues and commentaries)

Jeffrey Freeman, MD, University of Michigan, Ann Arbor, Mich.

Pediatric EM

Bruce Minnes, MD, Hospital for Sick Children, Toronto

Ran Goldman, MD, Hospital for Sick Children, Toronto

Niranjan Kissoon, MD, University of Florida HSC/Jacksonville,

Jacksonville, Fla.

Humour AND Humanity

Virginia Robinson, MD, Fernie District Hospital, Fernie, BC

Diagnostic Challenge

Robert McGraw, MD, Queen's University, Kingston, Ont.

INTERNATIONAL EM

Garth Dickinson, MD, University of Ottawa, Ottawa

Medical Mythology

Mel Herbert, MD, University of Southern California, Los Angeles

RESIDENT ISSUES

Jonathan Davidow, MD, University of Alberta, Edmonton

Cameron MacGougan, MD, University of Alberta, Edmonton
CJEM

Journal canadien de la médecine d'urgence

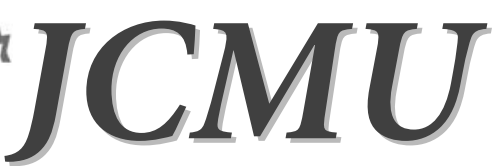

Vol. 6, No. 2, March / mars 2004

\section{TABLE OF CONTENTS • TABLE DES MATIÈRES}

LetTers • CourRIER

77

Potential error in the use of AEDs during an in-flight emergency, A. Holmes. Considering air embolism, J. Fitz-Clarke. Waiting Room medicine, L. Bryski. Role of SARS screening clinic in the ED, Wong Wing Nam. Correction.

\section{EM Advances • Innovations en MU}

Proportion of injured alcohol-impaired drivers subsequently convicted of an impaired driving criminal code offence in British Columbia

R.A. Purssell, M. Yarema, J. Wilson, M. Fang, R. Simons, S. Kasic, R.B. Abu-Laban, J. Brubacher, I. Lupu

Sentinel surveillance of HIV and hepatitis C virus in two urban emergency departments

S. Houston, B.H. Rowe, L. Mashinter, J. Preiksaitis, M. Joffe, D. Mackey, J. Galbraith, N. Wiebe

Utility of follow-up recommendations for patients discharged with community-acquired pneumonia

S.G. Campbell, D.D. Murray, D.G. Urquhart, D.M. Maxwell, S.A. Ackroyd-Stolarz, S.M. Varley-Doyle, M.D. Ells, A. Hawass

Screening urine for drugs of abuse in the emergency department: Do test results affect physicians' patient care decisions?

J.S. Eisen, M.L.A. Sivilotti, K.U. Boyd, D.G. Barton, C.J. Fortier, C.P. Collier

SMall URban and RURAL IsSUes

MÉdecine RURALE ET DES PETITS CENTRES URBAINS

Need for bedside emergency department ultrasonography:

case report of a ruptured ectopic pregnancy

E. Laviolette

ED AdMINISTRATION • L'ADMINISTRATION DE LA MU

Root cause analysis of laboratory turnaround times for patients in the emergency department

C.M.B. Fernandes, A. Worster, S. Hill, C. McCallum, K. Eva

\section{Medical Mythology • Mythes médicaux}

When the MAGIC stops: magnesium in acute coronary syndromes - a lesson in medical humility

S. Patrick, M. Herbert 
EDITORS AT LARGE / RÉDACTEURS OCCASIONNELS

Lance Brown, MD, MPH, FACEP, Loma Linda, Calif.

Jeffrey R. Brubacher, MD, Vancouver

Greta Cummings, BScN, MEd, RN, PhD, Edmonton

Jason Frank, MD, MA (Ed), Ottawa

Brian Goldman, MD, MCFP (EM), Toronto

Shane Neilson, BSc, MD, Halifax, NS

Marco Sivilotti, MD, MSc, Kingston, Ont

Christian Vaillancourt, MD, MSc, Ottawa

Andrew Worster, MD, MSc, Hamilton, Ont.

Web SITE

Jim Squires, MD_ jsquires2504@ rogers.com

Guelph General Hospital, Guelph, Ont.

Business AND Promotion

Chris Evans, MD cevans@ualberta.ca

University of Alberta, Edmonton

Translation / Traduction

Danielle Séguin-Tétreault, MTrad

Marketing and Advertising Sales / Marketing et publicité

Keith Health Care info@keithhealthcare.com

Toronto: 905 278-6700 or 800 661-5004; fax 905 278-4850

Montréal: 514 624-6979 or 877 761-0447; fax 514 624-6707

CJEM is owned by the Canadian Association of Emergency Physicians (CAEP) and printed by Dollco Printing, Ottawa.

CAEP Head Office: 1785 Alta Vista Dr., Ste. 104, Ottawa ON

K1G 3Y6; tel 613 523-3343; fax 613 523-0190; cjem@caep.ca

Editorial inquiries, submissions and all other correspondence: CJEM, c/o Dr. Grant Innes, Dept. of Emergency Medicine, St. Paul's Hospital, 1081 Burrard St., Vancouver BC V6Z 1Y6; 604 806-8980, fax 604 608-9810, ginnes@interchange.ubc.ca

Instructions for Authors, Service Information: see Table of Contents. Address changes or requests for permission to reproduce items in CJEM: contact Susan Norrington at the CAEP Head Office.

Publications mail agreement no. 0344505499. Return undeliverable Canadian copies to the CAEP Head Office. USPS periodical postage paid at Champlain, NY, and additional locations. ISSN 1481-8035.

We acknowledge the financial support of the Government of Canada, through the Canada Magazine Fund, toward our editorial costs.

\section{PAAB * Canadä}

All prescription drug advertisements have been cleared by the Pharmaceutical Advertising Advisory Board.

(C) 2004 Canadian Association of Emergency Physicians Association canadienne des médecins d'urgence

\section{Publisher / Éditeur}

CJEM is published every 2 months (January, March, May, July, September and November) for CAEP by the Canadian Medical Association, Ottawa. CAEP and the CMA assume no responsibility or liability for damages arising from any error or omission, or from the use of any information or advice contained in the journal, including articles, editorials, case reports, reviews, media reviews, letters and advertisements. All editorial matter in CJEM represents the opinions of the authors and not necessarily those of CAEP or the CMA

ACTING Director / Directeur PAR INTÉRIM, PublicATIONS

Lorne Ross

Associate Director, Publishing Services

DiRECTRICE ASSOCIÉE, SERVICES D'ÉDITION

Glenda Proctor, MSc, ELS

Editor / RÉdACtrice, Publications

Jennifer E. Raiche

800 663-7336 x2114; fax 613 565-2382; jennifer.raiche@cma.ca

PRODUCTION

Kathryn A. Freamo

Nicole Barbeau, Clara Walker

Classified Advertising / ANNONCES ClasséEs

Beverley Kirkpatrick, Deborah Rodd, Tracy Huckabone

613 731-8610 x2127/2314; fax 613 565-7488; advertising@cma.ca

DisPlay AdVERTISING / ANNONCES PUBLICITAIRES

Nancy Pope, 613 731-8610 x2111

\section{Case Report • Observations de cas}

Blunt traumatic rupture of the pericardium with cardiac herniation J.C.R. Rippey, S. Rao, D. Fatovich

\section{Diagnostic Challenge • Défi diagnostique}

Sick LADy; Answer

P.G. Katis

News • Nouvelles

Report on 2003 CAEP Research Grants Competition, E. Grafstein, for the CAEP Research Committee. Introducing a new Web site for aspiring EM physicians. In memory of Dr. Peter Lane.

\section{Calendar • Calendrier}

Classified Advertising • Annonces Classées

\section{INSTRUCTIONS FOR AUTHORS}

See January 2004 issue or visit www.caep.ca/cjem

INSTRUCTIONS POUR LES AUTEURS

Visitez www.caep.ca/cjem

\section{SERVICE INFORMATION}

See January 2004 issue or visit www.caep.ca/cjem

\section{SERVICES}

Voir le numéro de janvier 2004 ou visitez www.caep.ca/cjem

\section{AdVERTISERS' INDEX INDEX DES ANNONCEURS}

Abbott Laboratories, Limited

Biaxin XL Inside Front Cover, 137, 138

Pediatric Biaxin 74, 78

Innova Medical Ophthalmics

Morgan Lens 76

Pfizer Canada Inc.

Bextra 139, 140, Outside Back Cover

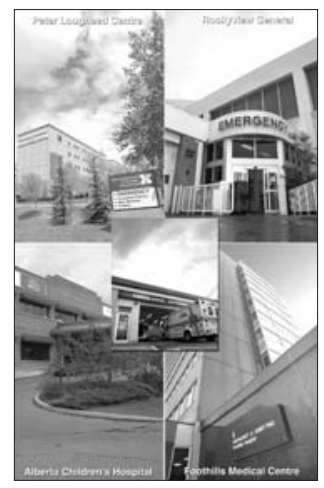

About the Cover:

Calgary emergency departments

Photos commissioned by Dr. Gil Curry, Regional Clinical Department Head of Emergency Medicine, Calgary Health Region.

Photos and compilation:

Dave Lowery, Be There Communications, Calgary 